\title{
Pemanfaatan barang bekas dalam bercocok tanam secara hidroponik bagi masyarakat pesisir
}

\author{
St. Fatmah Hiola ${ }^{1}$, Nur Anny Suryaningsih Taufieq ${ }^{2}$, Putri Humaira Salsabila ${ }^{3}$ \\ ${ }^{1}$ Fa kultas Matematika dan Ilmu Pengetahuan Ala m, Universitas Negeri Makassar \\ ${ }^{2}$ Fakultas Teknik, Universitas Negeri Makassar \\ ${ }^{3}$ Fa kultas Teknik, Universitas Hasanuddin
}

\begin{abstract}
One of the potentials that according to most people is worthless is rubbish. Garbage is a consequence of human activity. Pla stic wa ste is one of the types of waste whoseexistence dominates the human environment. One technique for reusing inorganic waste can be done by making used goods as agricultural containers, be sides being cheap, easy to obtain, durable, and also able to reduce the level of pollution to the environment. This de dication activity is carried out using training methods. The number of participants as many as 25 people who are communities around the coastal region, namely in the Villa ge Turikamaseng, Maros Regency, South Su lawesi Province. The results of the activities showed that the interests and skills of the community a fter a ten ding the tra ining a ctivities increased. The material given in the opinion of the community is quite in teresting a nd ca $\mathrm{n}$ be applied directly in their daily lives. The conclu sion that is able to provide a n understanding of the im portance of protecting the environment around us. In a ddition, the methods used in this a ctivity have been able to im prove the knowledge and skills of partner communities in terms of knowledge about hydroponic farming.
\end{abstract}

Key words: empowerment, hidroponic, pla stic wa ste

\section{PENDAhULUAN}

Dalam mengimplementasikan ilmu lingkungan, maka pendekatan yang dianggap paling sesuai adalah pendekatan kontekstual. Pendekatan kontekstual adalah konsep yang membantu dalam mengkaitkan antara teori dengan dunia nyata. Dengan pendekatan kontekstual dapat memotivasi peserta dalam membuat hubungan antara pengetahuan dan penerapannya dalam kehidupan mereka sehari-hari. Oleh karena itu dalam pelatih an ini, materi akan lebih mudah dipahami oleh peserta apabila media pembelajaran menggunakan benda-benda konkrit yang ada di sekitar kita.

Salah satu potensi yang menurut sebagian besar orang merupakan sesuatu hal yang tidak bernilai adalah sampah. Sampah merupakan konsekuensi dari adanya aktivitas manusia. Sampah plastik merupakan salah satu jenis sampah yang keberadaannya mendominasi lingkungan hidup manusia. Kerusakan lingkungan, pencemaran air dan tanah menyebabkan banyaknya ekosistem yang mati (Hadiwiyono, 1983).

Sampah plastik merupakan salah satu jenis sampah yang keberadaannya mendominasi lingkungan hidup manusia. Kerusakan lingkungan, pencemaran air dan tanah menyebabkan banyaknya ekosistem yang mati. Selain itu sampah plastik (termasuk botol bekas) yang terbuat dari bahan polyethylene terephthalate atau PET disinyalir mengandung zat karsinogen (penyebab kanker). Zat ini membahayakan tubuh jika terminum. Dari keseluruhan sampah plastik, sebagian besar diketahui belum termanfaatkan dengan baik. Sebenarnya berbagai cara penanganan limbah plastik telah dilakukan antara lain penimbunan darat, pembakaran/pengkremasian, daur ulang, pengurangan penggunaan plastik. Sementara penanganan sampah plastik yang terjadi dalam masyarakat selama ini antara lain dibakar, dijual di pabrik untuk didaur ulang, dan dimanfaatkan ulang.

Salah satu teknik pemanfaatan ulang sampahsampah anorganik tersebut dapat dilakukan dengan menjadikan barang bekas tersebut sebagai wadah untuk bercocok tanam, selain murah, mudah diperoleh, tahan lama, juga mampu mengurangi tingkat pencemaran terhadap lingkungan. Teknik bercocok tanam yang dimaksudkan adalah teknik 
budidaya tanaman dengan sistem hidroponik dan vertikultur.

Mengapa teknik ini yang dipilih?, karena teknik budidaya dengan sistem konvensional tersebut kurang tepat diterapkan pada daerah pesisir seperti Kabupaten Maros, karena merupakan daerah tambak, dimana kita ketahui bersama bahwa ketersediaan air tawar bersih cukup sulit dalam jumlah banyak, sehingga perlu dicarikan alternatif lain dalam pengembangan budidaya tanaman dalam rangka menunjang kebutuhan hidup sehat masyarakatnya. Hal tersebut tentunya dapat di siasati dengan memanfaatkan teknik bercocok tanam secara hidroponik dan vertikultur (Lingga, 2002). Melalui perbaikan teknik budidaya konvensional dengan pengenalan teknologi hidroponik dan vertikultur yang sederhana dan mudah diterapkan, baik oleh anak-anak hingga orang dewasa, sehingga siapa pun dapat menerapkannya di tempat yang terbatas sekalipun. Kelebihan penerapan teknik ini dapat mengatasi pemanfaatan lahan-lahan yang terbatas di sekitar kita, sekaligus membantu pihak pemerintah dalam mengatasi masalah sampah anorganik, khusunya sampah plastik, styrofoam, kaleng dan semacamnya.

Berdasarkan uraian tersebut maka diperlukan suatu kegiatan, khususnya bagi masyarakat dalam menyikapi fenomena sampah dan kebutuhan hidup sehat tersebut melalui pelatihan pemanfaatan barang bekas sebagai wadah tanam hidroponik.

\section{METODE PELAKSANAAN}

Metode kegiatan yang dilakukan dalam kegiatan PKM meliputi beberapa tahapan pelaksanaan.

\section{A. Tahap Persiapan}

Kegiatan yang dilakukan pada tahap ini adalah mengurus persuratan untuk pelaksanaan kegiatan, mulai dari perijinan tingkat universitas hingga ke tingkat mitra yaitu Kepala Desa Turikamaseng, Kabupaten Maros.

\section{B. Kegiatan Penyuluhan}

Pada tahap ini dilakukan dengan menggunakan metode ceramah dan demonstrasi. Metode ini digunakan untuk menyampaikan informasi singkat mengenai hidroponik, barang bekas, dan manfaatnya secara teoritis. Hal ini dimaksudkan agar peserta memiliki dasar-dasar ilmiah yag kuat dalam mengenal potensi barang bekas dan pemanfaatannya dalam bercocok tanam hidroponik. Sedangkan metode demonstrasi dilakukan untuk memperlihatkan bagaimana teknik bercocok tanam secara hidroponik, dan bagaimana memanfaatkan barang bekas dalam bercocok tersebut.

\section{Unjuk Kerja}

Pada tahap ini, peserta kegiatan PKM diberikan kesempatan untuk mengulangi langkah-langkah kerja yang sebelumnya telah ditunjukkan oleh narasumber saat kegiatan demonstrasi dilakukan. Tujuan kegiatan ini untuk meningkatkan kemampuan dan keterampilan peserta di dalam memanfaatkan barang bekas dan bagaimana Teknik bercocok tanam secara hidroponik.

\section{Diskusi}

Kegiatan terakhir ditutup dengan melakukan diskusi. Tujuan kegiatan ini agar peserta dapat saling bertukar informasi tentang pengalaman yang telah dilakukan, baik langkah-langkah yang telah dilakukan, kendala yang dihadapi, maupun keberagaman hasil yang akan diperoleh saat melakukan praktik.

\section{HASIL DAN PEMBAHASAN}

\section{A. Tahap Persiapan}

Tahap persiapan pada pelaksanaan kegiatan pengabdian masyarakat tahun 2019 di Desa Turikamaseng Kabupaten Maros, dimulai dengan pengurusan surat perijinan, baik pada tingkat universitas hingga ke tingkat Desa. Selanjutnya melakukan pertemuan dengan anggota Tim pelaksana yang membahas tentang persamaan persepsi, pembagian kerja, instruktur untuk pelatihan dan pendampingan, dan rangkain kegiatan yang akan dilakukan.

\section{B. Kegiatan Penyuluhan}

Kelompok sasaran pelatihan ini adalah ibu-ibu 
rumah tangga yang berdomisili di wilayah Desa Turikamaseng. Pelatihan ini merupakan yang pertama kali mereka ikuti. Sebelumnya pernah ada kegiatan pelatihan bercocok tanam, namun bukan secara hidroponik sehingga pelatihan ini sangat menarik bagi peserta. Hal ini dapat dilihat dari antusias peserta dalam mengikuti pelatihan.

Selanjutnya dilakukan sosialisasi tentang manfaat barang bekas seperti limbah botol plastik dan limbah styrofoam sebagai media cara bercocok tanam secara hydroponic.

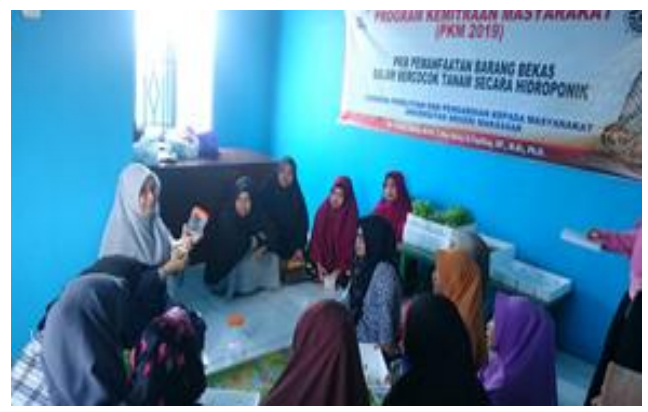

Gambar 1. Kegiatan penyuluhan melalui sosialisasi kepada masyarakat

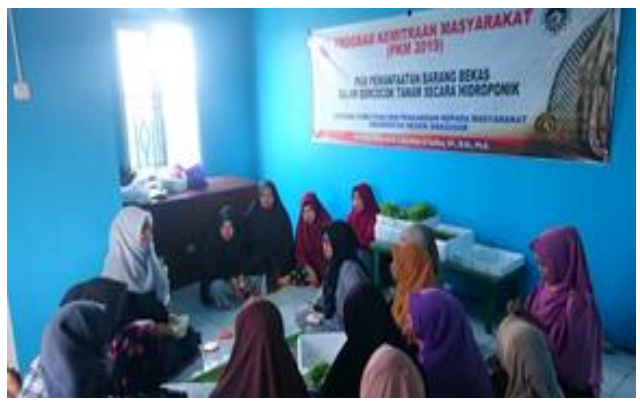

Gambar 2. Penyampaian materi dilakukan dengan ceramah dan demonstrasi

\section{Kegiatan Unjuk Kerja}

Pada tahap ini, peserta kegiatan PKM diberikan kesempatan untuk mengulangi langkah-langkah kerja yang sebelumnya telah ditunjukkan oleh narasumber saat kegiatan demonstrasi dilakukan. Tujuan kegiatan ini untuk meningkatkan kemampuan dan keterampilan peserta di dalam memanfaatkan barang bekas dan bagimana Teknik bercocok tanam secara hidroponik.

Selama proses kegiatan penyuluhan peserta terlihat sangat antusias menyimak penjelasan dari narasumber, sehingga pada tahap unjuk kerja ini mereka lebih antusias lagi untuk mempraktekkan- nya. Peserta dibagi dalam 5 (lima) kelompok, dimana setiap kelompok mulai memilih kebutuhan mereka. Tim pelaksana hanya menyiapkan bahan dan alat yang akan digunakan, sedangkan peserta diminta untuk menyiapkan semua bahan dan peralatan sesuai yang telah diajarkan sebelumnya.

Proses pelatihan dengan unjuk kerja ini dirasakan sangat bermanfaat bagi peserta, karena mereka dapat secara langsung mempratekkan langkah-langkah yang telah diajarkan sebelumnya. Sehingga jika ada kendala dapat langsung bertanya kepada narasumber (Gambar 3 dan Gambar 4).

Selain itu, dengan melakukan secara berkelompok secara tidak langsung juga memberikan pembelajaran kepada peserta, bagaimana menjalin kerjasama dalam kelompok.

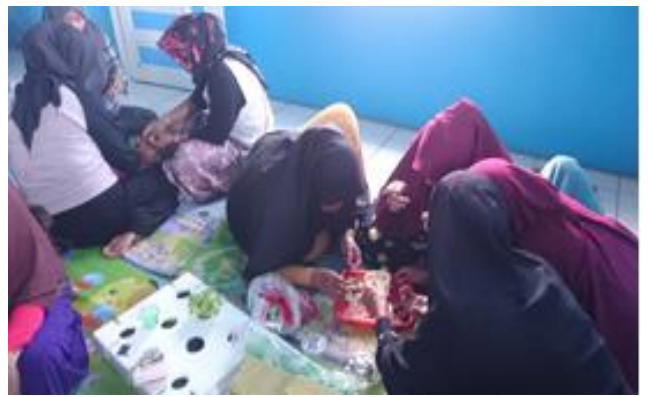

Gambar 3. Bekerjasama dalam menyiapkan bahan yang akan digunakan

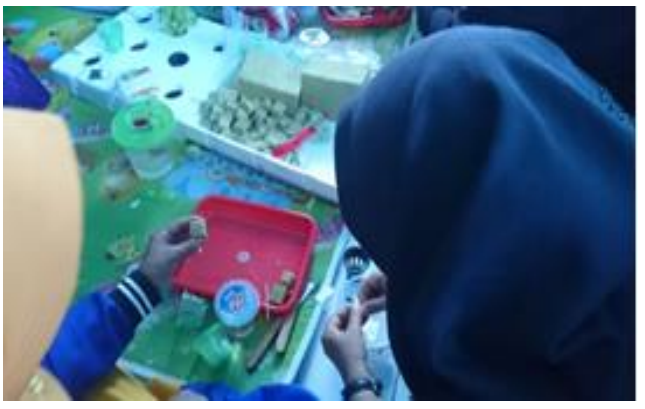

Gambar 4. Bekerjasama dalam menyiapkan persemaian benih

\section{Tahap Diskusi}

Setelah tahap unjuk kerja dilakukan, kemudian dilanjutkan dengan diskusi dan tanya jawab bagi peserta pelatihan. Kegiatan ini bertujuan untuk memberikan kesempatan bagi peserta jika ada halhal yang masih belum dipahami baik untuk ditanyakan (Gambar 5 dan Gambar 6). 


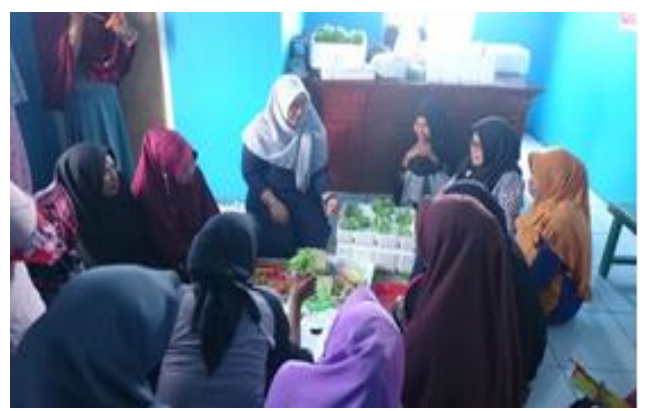

Gambar 5. Diskusi bersama peserta pelatihan

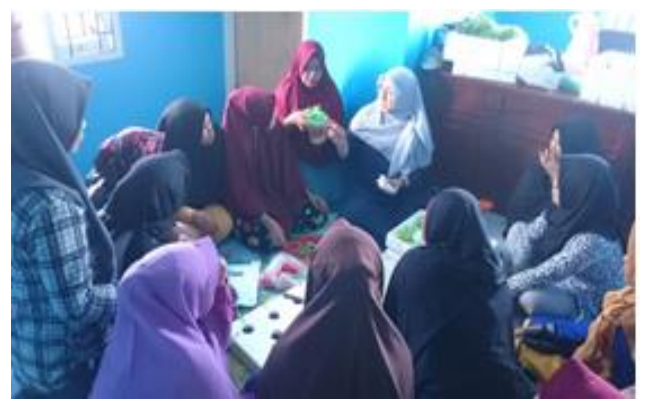

Gambar 6. Suasana tanya jawab bersama peserta pelatihan

Mengingat kegiatan ini merupakan hal yang baru bagi peserta, sehingga sangat antusias mengikuti dan mempelajari tahapan demi tahapan kegiatan. Beberapa kriteria yang dapat dijadikan sebagai indikator keberhasilan dari kegiatan pelatihan disajikan pada Tabel 1 .

Tabel 1. Indikator keberhasilan pelatihan

\begin{tabular}{ll}
\hline \multicolumn{1}{c}{ Kriteria } & \multicolumn{1}{c}{ Indikator } \\
\hline Tingkat & Kegiatan pelatihan diminati oleh \\
masyarakat desa mitra, karena peserta & yang hadir melebihi jumlah undangan. \\
\hline Tingkat & Dapat dilihat dari antusiasme peserta \\
Pemahaman & dalam mengikuti pelatihan mulai dari awal \\
& kegiatan hingga akhir, dan keaktifan \\
& peserta dalam kegiatan diskusi dan tanya \\
& jawab. \\
\hline Dampak & Peserta mampu mengulang kembali secara \\
Kegiatan & bertahap apa yang telah diajarkan \\
& sebelumnya melalui kegiatan unjuk kerja \\
& yaitu mempraktikkan cara bercocok tanam \\
& dengan hidroponik dan dapat meracik \\
& bahan-bahan yang diperlukan dalam \\
& membuat pupuk untuk media hidroponik. \\
\hline Kesesuaian & Menurut pendapat peserta, materi \\
& pelatihan yang diberikan sangat menarik \\
dan dapat mereka aplikasikan langsung di & rumah. Cara menyampaikan materi oleh \\
& narasumber sangat jelas dan terarah, \\
& sehingga peserta dapat dengan mudah \\
& memahami materi yang diajarkan. \\
\hline
\end{tabular}

Tabel 1 menunjukkan bahwa secara umum kegiatan pengabdian yang telah dilakukan dapat dikatakan berhasil. Beberapa faktor yang menjadi pendorong keberhasilan kegiatan:

1. Adanya keterlibatan mitra dalam kegiatan pelatihan.

2. Permasalahan yang dibahas tepat sasaran sehingga masyarakat sangat antusias ketika mengikuti setiap tahap kegiatan pengabdian masyarakat.

3. Narasumber yang memberikan pelatihan sangat komunikatif sehingga bisa menyatu dengan peserta baik secara formal maupun informal.

4. Solusi masalah sampah plastic bagi masyarakat mitra mendapatkan solusi.

5. Materi hidroponik merupakan hal yang baru bagi peserta.

\section{KESIMPULAN}

Kegiatan pelatihan pemanfaatan barang bekas sebagai media bercocok tanam hidroponik mampu memberikan pemahaman mengenai pentingnya menjaga lingkungan disekitar kita. Selain itu, metode yang digunakan pada kegiatan ini telah mampu meningkatkan pengetahuan dan keterampilan masyarakat mitra yaitu ibu-ibu rumah tangga Desa Turikamaseang Kabupaten Maros terkait pengetahuan tentang cara bercocok tanam secara hidroponik dengan teknik menggunakan botol bekas sebagai wadah hidroponik.

\section{DAFTAR PUSTAKA}

Hadiwiyono, S, 1983, Penanganan dan Pemanfaatan Sampah. Jakarta: Yayasan Idayu.

Lingga, P. 2002. Hidroponik Bercocok Tanam Tanpa Tanah. Penebar Swadaya, Jakarta. 